\title{
Cladocers, Copepods and Rotifers in rice-fish culture handled with metsulfuron-methyl and azimsulfuron herbicides and carbofuran insecticide
}

\author{
Cladocera, Copepoda e Rotifera em rizipiscicultura tratada com os herbicidas metsulfuron-metílico e \\ azimsulfuron e o inseticida carbofuran
}

\author{
Jaqueline Ineu Golombieski ${ }^{I}$ Enio Marchesan'II Joele Schmitt Baumart ${ }^{\mathrm{I}}$ \\ Geovane Boschmann Reimche ${ }^{\mathrm{III}}$ Charrid Resgalla Júnior ${ }^{\mathrm{IV}}$ Lindolfo Storck $^{\mathrm{II}}$ Sandro Santos ${ }^{{ }^{*}}$
}

\section{ABSTRACT}

This study determined the effects of metsulfuronmethyl, azimsulfuron and carbofuran in communities: Cladocers, Copepods and Rotifers that are present in irrigated rice farming with the rice-fish system. The field experiment was conducted in the 2004/05 growing season with eight treatments. The fish species were: Cyprinus carpio, Ctenopharyngodon idella and Aristichthys nobilis, introduced seven days after treatments were applied. Water samples were collected 17 days before and $1^{\text {st }}, 3^{\text {rd }}, 10^{\text {th }}$, $18^{\text {th }}, 31^{\text {th }}, 51^{\text {th }}$, and $75^{\text {th }}$ days after the agrochemicals were applied for identification and evaluation of the zooplankton. The results indicated that the herbicides did not affect the zooplankton community studied and carbofuran insecticide application provoked negative effects in Cladocers. Copepods and Rotifers were slightly affected by carbofuran.

Key words: agrochemicals, non-target organisms, zooplankton communities, rice culture.

RESUMO

O presente estudo determinou o efeito de metsulfuron-metílico, azimsulfuron e carbofuran nas comunidades: Cladocera, Copepoda e Rotifera presentes em lavouras de arroz irrigado com o sistema de rizipiscicultura. O experimento foi conduzido durante a safra agrícola 2004/05 com oito tratamentos. As espécies de peixes utilizadas foram: Cyprinus carpio, Ctenopharyngodon idella e Aristichthys nobilis, introduzidas sete dias após a aplicação dos tratamentos. Amostras de água foram coletadas 17 dias antes e no(s) 1ํㅡ. $3^{\circ}$, $10^{\circ}, 18^{\circ}, 31^{\circ}, 51^{\circ}$ e $75^{\circ}$ dias após a aplicação dos tratamentos para a identificação e a avaliação de zooplâncton. Os resultados indicam que os herbicidas estudados não afetaram a comunidade zooplanctônica e a aplicação do inseticida carbofuran provocou efeitos negativos em Cladocera. Copepoda e Rotifera foram pouco afetados pelo carbofuran.

Palavras-chave: agroquímicos, organismos não-alvos, comunidade zooplanctônica, lavoura arrozeira.

\section{INTRODUCTION}

Zooplankton communities play a key role in aquatic ecosystems by feeding on microalgae and particulate organic matter and serving as the main food to larvae and juvenile fishes. Moreover, these organisms are frequently employed in ecotoxicologic assays since they are one of the most sensitive groups to the effects of toxic chemical products, as well as they are in a central position in the lentic food chain (HANAZATO, 2001; GAGNETEN, 2002).

Once agrochemicals are extensively used in agriculture, their biocide activity increases the probability of negative impacts on non-target organisms, such as the aquatic biota (TREMOLADA et al., 2004; SÁNCHEZ-BAYO \& GOKA, 2006). Nevertheless, most of the information about the toxicity of these compounds is based on laboratorial tests, and the combined effect of agrochemical is seldom studied (BARRY \& LOGAN, 1998; WENDT-RASH et al., 2003).

\footnotetext{
IDepartamento de Biologia, Setor de Zoologia, Universidade Federal de Santa Maria (UFSM), 97105-970, Santa Maria, RS, Brasil. E-mail: ssantos@smail.ufsm.br.*Autor para correspondência.

IIDepartamento de Fitotecnia, UFSM, Santa Maria, RS, Brasil.

IIIDepartamento de Defesa Fitossanitária, UFSM, Santa Maria, RS, Brasil

IV Universidade do Vale do Itajaí, UNIVALI, Itajaí, SC, Brasil.
} 
In the Rio Grande do Sul (RS) State, Brazil, irrigated rice cultures are pointed out as the main environmental contaminants, due to the utilization of a great number and quantities of agrochemicals, which are later liberated in the environment and could reach the hydrous source. A system which emerges as an alternative to reduce the agrochemicals application in rice cultures, in the pre-germinated cultivation system, is the rice-fish culture, that is the associated irrigated rice cultivation and fish culture. This system also reduces the use of field machines (MARCHEZAN et al., 2006).

In this system, the polycultive of carps is employed, because different species of carps present different feeding habits and thus do a better field preparation. The common carp Cyprinus carpio has omnivorous feeding habit consuming seeds, earthworms, insects, small mollusks and so on, and which removes the soil searching for food (LAMMENS et al., 1991). The grass carp Ctenopharyngodon idella, has herbivorous feeding habit (YANG et al., 1990) and the bighead carp Aristichthys nobilis is zooplanktofagous (CREMER \& SMITHERMAN, 1980). However, in some situations, only the fish utilization in the field is not enough to improve the production levels in the rice culture, making necessary the application of herbicides and insecticides (HALWART, 2001).

The carbofuran insecticide (carbamato group) is utilized for the insect control, as for Oryzophagus oryzae larvae (rice water weevil), which can reduce the rice culture productivity in up to $10 \%$ (MARTINS et al., 2004). The azimsulfuron herbicide is used for the control of Sagittaria sp. (arrow-head), Cyperus sp. (sedges) and Fimbristylis sp. (fimbristyles), and metsulfuron-methyl is used for the control of Aeschynomene sp. (jointvetch) and Heteranthera sp. (mud plantain) (SOSBAI, 2003), important invader plants in rice culture.

As there are few studies in field focusing on the effect of agrochemical on zooplankton communities, the aim of this study was to determine the effects of metsulfuron-methyl, azimsulfuron and carbofuran on the Cladocers, Copepods (adults and nauplii) and Rotifers communities present in irrigated rice cultures with the system of rice-fish culture system.

\section{MATERIALS AND METHODS}

Experiments were carried out at Universidade Federal de Santa Maria (UFSM - Rio Grande do Sul State, Brazil) throughout the harvest time of irrigated rice culture in 2004/2005, during October
2004 to March 2005 in a systematized holm area. The randomized block experimental design was used, in a two-factor way (treatment $x$ days), with four replications. The experimental units (plots) were $48 \mathrm{~m}^{2}(8 \times 6 \mathrm{~m})$, with refuge (side trench to shelter the fish, measuring $5.3 \mathrm{~m}$ in length $\mathrm{x} 0.7 \mathrm{~m}$ width $\mathrm{x} 0$. $\mathrm{m}$ deep), representing about $8 \%$ of the total area of plots. The rice was sowed in the pre-germinated culture system in $10 / 22 / 2004$, and the water lamina was kept about $0.10 \mathrm{~m}$ in height during all the culture cycle.

The fish species utilized were: $60 \%$ common carp (8.7 $\pm 0.82 \mathrm{~g}) ; 20 \%$ grass carp (13.2 $\pm 2.72 \mathrm{~g})$ and $20 \%$ bighead carp (16.4 $\pm 0.25 \mathrm{~g})$, which were introduced into the plots, in the refuge areas, at the seventh day after the treatments' application, at the settlement density of 20.000 fingerlings $\mathrm{ha}^{-1}$. The fish proportion utilized was those recommended for rice-fish culture in Rio Grande do Sul, State, Brazil, according to species feeding habits (COTRIM, 2000).

Agrochemicals were applied 30 days after the rice seeding at the following concentrations: Ally ${ }^{\circledR}$ (metsulfuron-methyl) - 3.3g ha-1 (1.98g i.a. ha-1), Gulliver $^{\circledR}$ (azimsulfuron) - $5 \mathrm{~g} \mathrm{ha}{ }^{-1}\left(5 \mathrm{~g}\right.$ i.a. ha $\left.\mathrm{h}^{-1}\right)$, and Diafuran 50G ${ }^{\circledR}$ (carbofuran) - 1500g ha ${ }^{-1}$ (750g i.a ha ${ }^{-1}$ ) (SOSBAI, 2003). The treatments utilized were: [T1] azimsulfuron in rice-fish culture; [T2] metsulfuronmethyl in rice-fish culture; [T3] carbofuran in rice-fish culture; [T4] azimsulfuron, metsulfuron-methyl and carbofuran in rice-fish culture; [T5] azimsulfuron, metsulfuron-methyl and carbofuran in area with rice only; [T6] azimsulfuron and metsulfuron-methyl in ricefish culture; [T7] control 1 (only rice, without agrochemicals); [T8] control 2 (rice-fish culture without agrochemicals).

While realizing the experiment, water samples of 1L from each plot were collected and conditioned in amber glass flasks, and sent to the Laboratory of Analysis of Pesticide Residues (LARP) at UFSM. Samplings were realized before the agrochemicals' application and among the first and the $75^{\text {th }}$ days after application. The products were analyzed by High Performance Liquid Chromatography with detection at ultraviolet light (HPLC-UV), following the methodology described by ZANELLA et al. (2000).

The water physical-chemical parameters were monitored in the course of the experiment, at the moment of zooplankton samplings, with the measure of $\mathrm{pH}$ (pHmeter Schott Handylab 1), total hardness (APHA, 1992), temperature and dissolved oxygen (oxymeter Oakton), total alkalinity (APHA, 1992) and determination of the water transparency (Secchi Disk).

Water samples were collected from the plot, in the refuge areas, in eight distinct periods: 17 days 
before the application $\left(17^{\text {th }} \mathrm{DBA}\right)$ and at the $1^{\text {st }}, 3^{\text {rd }}, 10^{\text {th }}$, $18^{\text {th }}, 31^{\text {st }}, 51^{\text {st }}$, and $75^{\text {th }}$ days after application (DAA) (November 2004 to February 2005). The samplings were carried out from 4h30min to 6h30min am, with a plankton collecting net ( $25 \mu \mathrm{m}$ mesh), when the samples were fixed in formaldehyde $4 \%$. At the laboratory, the samples were concentrated to $60 \mathrm{~mL}$. Subsamples of $1 \mathrm{~mL}$ were taken with a volumetric pipette and transferred to Bogorov plates for quali-quantitative analysis of the zooplanktonic groups, under a stereoscopy microscopy.

The results of the zooplankton groups' density were submitted to the two-factor (treatment and days) analysis of variance (ANOVA), for the evaluation of the interaction between them. The means were compared by the Tukey test $(\mathrm{P}<0.05)$ to determine the differences among treatments. The Analysis of Canonical Correlation (CRUZ \& REGAZZI, 1994) was employed to verify the associations between the water physical-chemical parameters (group I) and the zooplankton community (group II).

\section{RESULTS AND DISCUSSION}

The mean physical-chemical parameters of the water throughout the experiment were (minimun and maximun): dissolved oxygen (0.6-2.2 $\mathrm{mg} \mathrm{L}^{-1}$ ), temperature $\left(17.6-25.7^{\circ} \mathrm{C}\right), \mathrm{pH}(6.4-7.0)$, total hardness (26-74mg L ${ }^{-1} \mathrm{CaCO}_{3}$ ), total alkalinity (16-31 $\left.\mathrm{mg} \mathrm{L}^{-1} \mathrm{CaCO}_{3}\right)$ and water transparency $(20-50 \mathrm{~cm})$.

Canonical pairs were significant only for the first order (canonical correlation equal to 0.83) $(\mathrm{P}<0.01)$. The considered groups (water physical-chemical parameters and zooplankton groups) were not independent and the inter-group associations were established in the following way: when the temperature and total hardness (concentration of calcium and magnesium ions) of the water were lower and the water transparency was higher, the Copepods (adults and nauplii) group was found at greater density.

Concerning the application of metsulfuronmethyl and azimsulfuron to the experiment, in the first water sampling performed about 12 hours after the treatment application, the presence of these herbicides was not detected (detection limit - LOD $=0.001 \mathrm{mg} \mathrm{L}^{-1}$ ). However, carbofuran was detected in the rice culture up to 17 days after its application, with a value of $0.013 \mathrm{mg} \mathrm{L}^{-1}$ (4\% of the initial dose), demonstrated that this value meeting under of the maximum contamination level $\left(0.04 \mathrm{mg} \mathrm{L}^{-1}\right)$ for drinking water, according to U.S. Environmental Protection Agency (EPA, 2006).
No significant difference among treatments was found for the Cladocers group at the $17^{\text {th }} \mathrm{DBA}$. At the first DAA, there was difference between the treatments T4 and T5 in relation to the control 1 (T7). For the treatment T6, which combined the two herbicides, a density of organisms $\mathrm{L}^{-1}$ significantly greater than the control 1 (T7) was observed. Also, at the third DAA, this pattern was kept for the treatments that utilized carbofuran (T3, T4 and T5), with an accentuated decrease in the density of this group. From the $10^{\text {th }} \mathrm{DAA}$ to the $75^{\text {th }}$, no significant differences were obtained among treatments (Table 1). Concerning the sampling days, it was observed a tendency in decreasing the Cladocers community from the $10^{\text {th }}$ DAA.

In the present study, the Cladocers group was the most sensitive to the effect of the carbofuran agrochemical (treatments T3, T4 and T5), when compared to the other zooplanktonic groups, since at the $3^{\text {rd }}$ DAA an accentuated decline of this group's density was observed. Although T4 and T5 presented mixture with the herbicides, the isolated application of metsulfuron-methyl or azimsulfuron, or even their association, did not differ significantly from the control treatment 1 (T7), and did not affect negatively this group.

The present results are in accordance to HANAZATO (1991), who utilized the insecticide carbaryl (carbamato group) in experimental tanks in Japan and found that Cladocers was more sensitive to this agrochemical than Rotifers which presented low sensitivity. RELYEA (2005) studied several agrochemicals, including the effect of the insecticide carbaryl on zooplankton (Cladocers and Copepods) and verified that at the low concentration tested in laboratory ( $0.51 \mathrm{mg} \mathrm{L}^{-1}$ of carbaryl) a rapid elimination of Cladocers (D. pulex, D. ambigua, D. longiremis, Ceriodaphnia sp. and Scapholebris sp.) occurred in two weeks of experiment, contributing for a biodiversity decline. HERBRANDSON et al. (2003) evaluated the effect of carbofuran (concentrations from 0 to $0.16 \mathrm{mg} \mathrm{L}^{-1}$ ) in combination to solids in suspension (from 0 to $10 \mathrm{mg} \mathrm{L}^{-1}$ ) for Daphnia magna (Cladocers) and verified that at the carbofuran concentration of $0.159 \mathrm{mg} \mathrm{L}^{-1}$, without the add of solids in suspension to the water, for a $48 \mathrm{~h}$ period, $98 \%$ of the Daphnia population were affected, with $\mathrm{EC}_{50}-48 \mathrm{~h}$ (effective concentration) of $0.092 \mathrm{mg} \mathrm{L}^{-1}$.

For the Rotifers group, a significant decrease in the density was observed for treatments $\mathrm{T} 2$ and T6 in relation to control 1 (T7) and T3 at the first DAA. From the third DAA up to the end of samplings (75 ${ }^{\text {th }}$ DAA), no significant differences were found among treatments (Table 1). For the sampled days in 
Table 1 - Population density (organisms $\mathrm{L}^{-1}$ ) of Cladocers, Rotifers and Copepods (adults and nauplii) from November/2004 to February/2005.

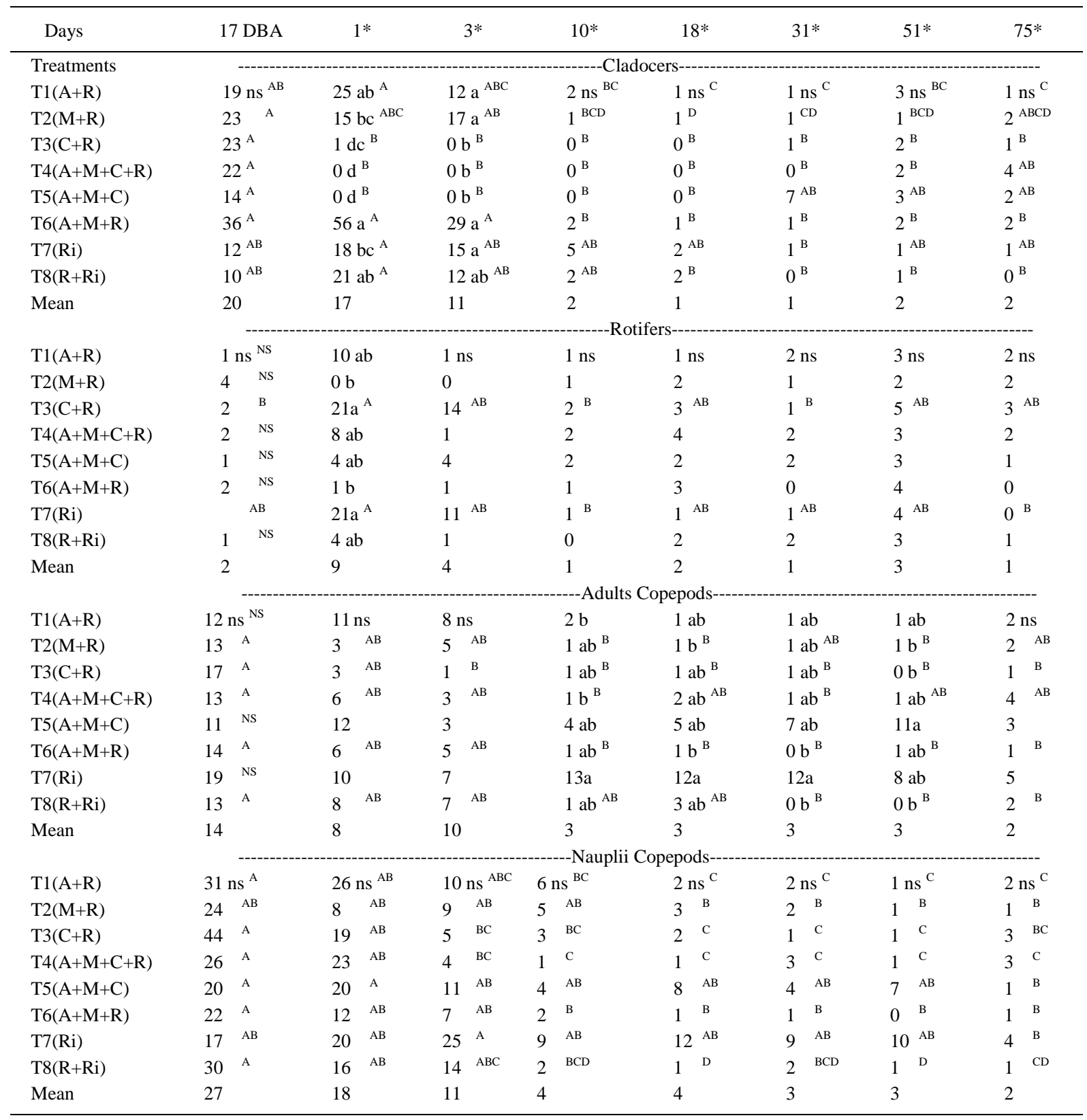

Means followed by distinct minuscule letters at columns and by capital letters at lines differ from each other by the Tukey test $(P<0.05)$. Ns = F test non-significant at column and NS = F test non-significant at line.

DBA = days before agrochemical application.

*1 to 75 = days after agrochemical application.

(A) Azimsulfuron; (M) Metsulfuron-methyl; (C) Carbofuran; (R) Rice-fish culture; (Ri) = Rice.

treatments T7 and T3, significant differences were found at the $10^{\text {th }} \mathrm{DAA}$, in relation to the first DAA, and only in T3 at $31^{\text {th }}$ DAA.

In general, the Rotifers group was little affected by the agrochemical treatments, conserving low densities along the experiment. These data are in agreement with those from HAVENS \& HANAZATO (1993), who observed that Rotifers was the less sensitive zooplankton group in acidified lakes and in the presence of agrochemicals at the environment, presenting a great diversity of species besides being high tolerant taxon. NEVES et al. (2003) stated that 
Rotifers possess wide tolerance to the variability of environmental factor due to its small size and short life cycle.

Significant differences were not observed between treatments at the $17^{\text {th }} \mathrm{DBA}$ and the $1^{\text {st }}$ and $3^{\text {rd }}$ DAA for the group Adult Copepods. At the $10^{\text {th }}$ DAA there was a significant difference between the treatment T4 and the control treatment 1 (T7). At the $18^{\text {th }}$ DAA the treatments $\mathrm{T} 2$ and $\mathrm{T} 6$ presented means significantly lesser than the control 1 (T7). At the $31^{\text {st }} \mathrm{DAA}$, control 1 (T7) presented organisms density significantly greater than T6 and T8. At the $51^{\text {st }} \mathrm{DAA}$ the treatments T2, T3 and T8 differed from treatment T5. Nevertheless, at the $75^{\text {th }}$ DAA no significant differences were observed in adult Copepods among treatments (Table 1). For the sampled days' analysis, no differences were observed among days in each treatment applied for Adult Copepods.

For the Nauplii Copepods no significant differences were observed among treatments at all sampled days (Table 1). Among the sampled days for each treatment, significant differences were observed for treatments $\mathrm{T} 1, \mathrm{~T} 3, \mathrm{~T} 4$ and $\mathrm{T} 8$ between the $1^{\mathrm{st}} \mathrm{DAA}$ and the $18^{\text {th }}$ DAA.

Little influence of agrochemicals treatments was observed for adult and nauplii Copepods. According to NEVES et al. (2003), the high density of immature forms of Copepods is due to the continuous reproduction of these organisms in tropical regions. The feeding habits of Copepods vary with the life phase at which they are, since adult Copepods can be carnivorous (predators), detritivores and filtrators, whereas nauplia are filtrators, and frequently herbivorous. It is important to point out that within the zooplankton community there is competition for food (bacteria, unicellular algae, among others) and even intra and interspecific predation.

A factor that can determine the proportion between young and adult forms is the intensive predation by invertebrates and vertebrates. At the present study, the fish introduction to the plots seven days after the treatments application did not alter the evaluated zooplankton density (nor increase or decrease), despite the colonization only by the bighead carp, which is zooplanktofagous.

Evidences indicate that natural stressors can modify the sensitivity of the zooplankton community exposed to agrochemicals, so that these organisms are more sensitive to agrochemicals at natural environments than if they are cultivated at controlled conditions in laboratory (LUGO et al., 1998). This could take place because at the natural environment the organisms are exposed to mixtures of chemical compounds, which when combined can cause behavioral, physiological and biochemical changes, death or other adverse effects (HERBRANDSON et al., 2003). In this case, agrochemicals can affect the interactions in the zooplankton community and cause secondary effects to the structure and composition of the biological community (HANAZATO, 2001; VILLARROEL et al., 2003). According to GAGNETEN (2002), the interaction between agrochemicals and biological factors can reduce or increase the consequences of the aquatic environment contamination. PRATT \& BARREIRO (1998) comment that agrochemicals can induce an accentuated decrease of the zooplankton community, mainly herbivorous crustaceans (Cladocers and Copepods Calanoides), because they determine reduction of trophic locals and changes in the algae structural communities.

The crescent order of sensitivity to the agrochemical carbofuran was: Nauplii Copepods $<$ Adult Copepods $<$ Rotifers $<$ Cladocers. So, the present study demonstrated that adverse effects occurred to the zooplankton community as consequence of exposition of the aquatic ecosystem organisms to the carbofuran.

\section{CONCLUSION}

It can be concluded that the herbicides did not affect the zooplankton community studied and the application of the agrochemical carbofuran cause negative effects to the zooplankton community from the rice farming, in system of rice-fish culture, for the Cladocers group. Copepods (adults and nauplii) and Rotifers are little affected by the application of this agrochemical.

\section{ACKNOWLEDGEMENT}

The authors thank to UFSM e CNPq (Conselho Nacional de Desenvolvimento Científico e Tecnológico) for financial support and to Dr. Bernardo Baldisserotto and Dra Marlise Ladvocat Bartholomei Santos for the critical reading of the manuscript.

\section{REFERENCES}

APHA - American Public Health Association. Standard methods for examination of water and wastewater. 18.ed. Sprinfield: Bru-El Graphic, 1992. 1155p.

BARRY, M.J.; LOGAN, D. The use of temporary pond microcosma for aquatic toxicity testing: direct and indirect effects of endosulfan on community structure. Aquatic Toxicology, Amsterdam, v.41, p.101-124, 1998. 
CREMER, M.C.; SMITHERMAN, R.O. Food habits and growth of silver and bighead carp in cages and ponds. Aquaculture, Amsterdam, v.20, p.57-64, 1980.

COTRIM, D.S. Rizipiscicultura: um sistema agroecológico de produção. In: Agroecologia e desenvolvimento rural sustentável. Porto Alegre: EMATER, 2000. p.14-18.

CRUZ, C.D.; REGAZZI, A.J. Modelos biométricos aplicados ao melhoramento genético. Viçosa: UFV, 1994. 390p.

EPA. 2006 Edition of the Drinking Water Standards and Health Advisories. Washington, D.C.: U.S. Environment Protection Agency. Office of Water, 2006. (EPA 822-R-06-013).

GAGNETEN, A.M. Efectos del herbicida paraquat sobre el zooplancton. Iheringia, Porto Alegre, v.92, p.47-56, 2002.

HALWART, M. Fish as a component of integrated pest management in rice production. In: FAO/ICLARM/IIRR. Integrated agriculture-aquaculture - a primer. Roma: FAO Fish. Tech., 2001. 149p. p.115-117. Pap.407.

HANAZATO, T. Effects of repeated applicationof carbaryl on zooplankton communities in experimental ponds with or without the predator Chaborus. Environmental Pollution, Oxford, v.74, p.309-324, 1991.

HANAZATO, T. Pesticide effects on freshwater zooplankton: an ecological perspective. Environmental Pollution, Oxford, v.112, p.1-10, 2001.

HAVENS, K.E.; HANAZATO, T. Zooplankton community responses to chemical stressors: a comparison of results from acidification and pesticide contamination research. Environmental Pollution, Oxford, v.82, p.277-288, 1993.

HERBRANDSON, C. et al. Influence of solids on acute toxicity of carbofuran to Daphnia magna: I. Interactive effects. Aquatic Toxicology, Amsterdam, v.63, p.333-342, 2003.

LAMMENS, E. et al. Diets and feeding behavior. In: WINFIELD, I.; NELSON, J. Cyprinid fishes. London: Chapman and Hall. 1991. p. 353-376.

LUGO, A. et al. Effect on the planktonic community of the chemical program used to control water hyacinth (Eichhornia crassipes) in Guadalupe Dam, Mexico. Aquatic Ecosystem Health and Management, New York, v.1, p.333-343, 1998.

MARCHEZAN, E. et al. Produção integrada de arroz irrigado e peixes. Ciência Rural, Santa Maria, v.36, n.2, p. 411-417, 2006.
MARTINS, J.F.S. et al. Descrição e manejo integrado de insetospraga em arroz irrigado. In: GOMES, A.S.; JÚNIOR, A.M.M. Arroz irrigado no Sul do Brasil. Brasília, DF: Embrapa Informação Tecnológica, 2004. Cap.19, p.635-675.

NEVES, I.F. et al. Zooplankton community structure of two marginal lakes of the river Cuiabá (Mato Grosso, Brazil) with analysis of Rotifera and Cladocera diversity. Brazilian Journal Biology, São Carlos, v.63, p.329-343, 2003.

PRATT, J.R.; BARREIRO, R. Influence of trophic status on the toxic effects of a herbicide: a microcosms study. Archives of Environmental Contamination and Toxicology, New York, v.35, p.404-441, 1998.

RELYEA, R.A. The impact of inseticides and herbicides on the biodiversity and productivity of aquatic communities. Ecological Applications, Washington v.15, p.618-627, 2005.

SÁNCHEZ-BAYO, F.; GOKA, K. Influence of light in acute bioassays of imidacloprid and zinc pyrithione to zooplankton cruataceans. Aquatic Toxicology, Amsterdam, v.78, p.262271, 2006.

SOCIEDADE SUL-BRASILEIRA DE ARROZ IRRIGADO (SOSBAI). Arroz irrigado: recomendações técnicas da pesquisa para o Sul do Brasil. Itajaí, SC: SOSBAI, 2003. $126 p$.

TREMOLADA, P. et al. Quantitive inter-apecific chemical activity relationships of pesticides in the aquatic environmental. Aquatic Toxicology, Amsterdam, v.67, p.87-103, 2004.

VILLARROEL, M. J. et al. Acute, chronic and sublethal effects of the herbicide propanil on Daphnia magna. Chemosphere, Oxford, v.53, p.857-864, 2003.

WENDT-RASH, L. et al. Effects of metsulfuron methyl and cypermethrin exposure on freshwater model ecosystems. Aquatic Toxicology, Amsterdam, v.63, p.243-256, 2003.

YANG, H.Z. et al. The biological effects of grass carp (Ctenopharyngodon idella) on filter-feeding and omnivorous fish in polyculture. In: HIRANO, R.; HANYU, I. (Eds.). The second asian fisheries forum. Manila, Philippines: Asian Fisheries Society, 1990. p.197-200.

ZANELLA, R. et al. Development and validation of a highperformace liquid chromatographic procedure for the determination of clomazone residues in surface water. Journal of Chromatography A, Amsterdam, v.904, p.257-262, 2000. 